
RESEARCH AND DEVELOPMENT

\author{
http://journal.unnes.ac.id/sju/index.php/higeia
}

\title{
DISTRIBUSI SPASIAL VEKTOR POTENSIAL FILARIASIS DAN HABITATNYA DI DAERAH ENDEMIS
}

\section{Fitriyana $^{\bowtie}$, Dyah Mahendrasari Sukendra, Rudatin Windraswara}

Epidemiologi dan Biostatistika, Jurusan Ilmu Kesehatan Masyarakat, Fakultas Ilmu Keolahragaan, Universitas Negeri Semarang

\section{Info Artikel}

Sejarah Artikel:

Diterima Februari 2018

Disetujui Maret 2018

Dipublikasikan April

2018

Keywords:

Vector, Habitat, Bedono,

Filariasis, spatial

\begin{abstract}
Abstrak
Desa Bedono merupakan wilayah desa endemis filariasis di Kabupaten Demak sejak tahun 2016 dengan $m f$ rate sebesar $>1 \%$. Penelitian ini dilakukan pada tahun 2017 dan bertujuan menggambarkan vektor potensial filariasis dan habitatnya yang dilihat secara spasial. Jenis penelitian ini adalah observasional dengan metode deskriptif. Pengumpulan data dilakukan dengan survei entomologi, pengambilan titik subjek, dan objek penelitian menggunakan GPS. Data dianalisis dengan analisis univariat dan secara spasial/pemetaan dengan perangkat Sistem Informasi Geografis (GIS). Hasil penelitian menunjukkan bahwa vektor potensial filariasis yaitu Culex vishnui dengan distribusi tertinggi pada area pemukiman. Habitat vektor potensial filariasis berupa drum air, selokan, kolam ikan, ban bekas, tambak, dan tempat minum ternak. Distribusi keberadaan habitat perkembangbiakan nyamuk paling banyak ditemukan di Dusun Morosari yang menyebar di jarak 100 meter dari kasus filariasis. Simpulan penelitian ini yaitu nyamuk yang berpotensi sebagai vektor filariasis di Desa Bedono adalah Culex vishnui dengan habitat terbanyak di area pemukiman (terutama Dusun Morosari).
\end{abstract}

\section{Abstract}

Bedono village was categorized as a fialriasis endemic region in Demak regency since 2016 with $\mathrm{mf}$ rate of $>$ 1\%. The study was conducted in 2017 and it was purposed to plot the spread of disease vector and its habitat through mapping. This research was an observational research with descriptive method as its research design. Data collection was conducted by entomological survey and GPS marking. Data were analyzed using univariate analysis and spatial analysis with GIS. The result shown that the potential vector of filariasis was Culex vishnui. The breeding places of the potential vector was a water drum, an open sewerage, a fish pond, used tires, ponds, and livestock. The distribution of mosquito breeding habitat was mainly found in Morosari which is spread in a distance of 100 metres from filariasis cases. The conclusion of the research that the potential vector of filariasis was Culex vishnui with the most habitat of Culex vishnui in settlement area (especially in Morosari Village). 


\section{PENDAHULUAN}

Filariasis adalah penyakit menular menahun yang disebabkan oleh parasit berupa cacing filaria, yang terdiri dari tiga spesies yaitu Wuchereria bancrofti, Brugia malayi dan Brugia timori. Penyakit filariasis masih menjadi beban dunia dikarenakan dapat menimbulkan kesakitan dan kecacatan yang tinggi berupa pembesaran kaki, lengan, payudara, dan skrotum (WHO, 2015). Cacat yang timbul akibat penyakit ini tidak hanya menghambat produktivitas, akan tetapi para penderita juga merasakan tekanan mental dan sosial karena stigma yang muncul di masyarakat (WHO, 2016). Selain itu, filariasis tidak memperlihatkan suatu gejala yang berarti hingga infeksi cacing filaria telah mencapai 10-15 tahun masa infeksi. Infeksi filariasis memiliki tiga tahapan penyakit, yaitu asimptomatik (tanpa gejala klinis), akut, dan kronis (WHO, 2016).

Fakta yang ditunjukkan dari data World Health Organization (WHO) tahun 2016 menyebutkan bahwa terdapat $1,5 \mathrm{M}$ orang terinfeksi filariasis dengan sekitar 40 juta mengalami cacat fisik dan keterbatasan dalam beraktivitas. Sekitar $65 \%$ penduduk berisiko tinggal di kawasan Asia Tenggara (WHO, 2016). Indonesia merupakan salah satu negara di Asia Tenggara dimana lebih dari 100 juta orang berisiko untuk terinfeksi filariasis, angka ini mempati urutan kedua setelah negara India (Naito, 2015). Kasus filariasis di Indonesia tersebar luas hampir di seluruh wilayah kepulauan seperti Sumatera, Jawa, Kalimantan, Sulawesi, Nusa Tenggara, dan Papua. Jumlah kasus filariasis di Indonesia dari tahun 2012 hingga tahun 2014 mengalami peningkatan. Secara berturut-turut angka penderita filariasis sebesar 11.903 kasus, 12.714 kasus, dan 14.932 kasus. Selain itu, tingkat endemisitas di Indonesia berkisar antara $0 \%-40 \%$ dengan endemisitas setiap provinsi dan kabupaten berbeda-beda. Berdasarkan survei darah jari hingga tahun 2014, kabupaten/kota di Indonesia yang endemis filariasis adalah 335 kabupaten/kota dari 495 kabupaten/kota (67\%), 3 kabupaten/kota yang tidak endemis filariasis
(0,6\%), dan 176 kabupaten/kota yang belum melakukan survei endemisitas filariasis. Pada tahun 2014, 176 kabupaten/kota tersebut disurvei dan endemisitas filariasis meningkat menjadi 356 dari 495 kabupaten/kota atau sebesar 71,9 \% (Kemenkes RI, 2015).

Kabupaten Demak merupakan salah satu daerah endemis filariasis di Jawa Tengah sejak dilakukan survei darah jari pada tahun 2009 dengan angka mikrofilaria rate (MfR) $1 \%$. Jumlah kasus filariasis Kabupaten Demak pada tahun 2015 yaitu 23 kasus, angka ini meningkat dibandingkan tahun 2014 yang hanya 19 kasus. Pada tahun 2016, kasus filariasis di Kabupaten Demak mengalami peningkatan tertinggi (10 kasus) pada kurun waktu 2015-2016. Dengan demikian kasus filariasis di Kabupaten Demak meningkat selama 3 tahun berturut-turut (Dinkes Kabupaten Demak, 2016).

Data dari Dinas Kabupaten Demak menyebutkan bahwa 3 besar penyumbang kasus filariasis di Kabupaten Demak hingga tahun 2016 yaitu Kecamatan Bonang (9 kasus), disusul oleh Kecamatan Karang Tengah (6 kasus), dan Kecamatan Sayung (4 kasus) (Dinkes Kabupaten Demak, 2016). Pada tahun 2016, Kecamatan Sayung ditemukan kasus paling banyak yaitu 3 kasus baru dibandingkan dengan Kecamatan Bonang dengan 1 kasus. Selain itu, kasus filariasis tertinggi di Kecamatan Sayung terdapat di Desa bedono dan merupakan fenomena KLB karena sebelumnya tidak ditemukan kasus filariasis.

Desa Bedono menjadi daerah perhatian filariasis dikarenakan hasil SDJ tahun 2016 menunjunkkan angka mikrofilaria rate penduduk sebesar $>1 \%$ ( 2 penduduk positif mikrofilaria Wuchereria bancrofti dari 150 penduduk yang diperiksa) dan terdapat penderita dengan gejala klinis pembengkakan pada bagian kaki (Dinkes Kabupaten Demak, 2016). Tingginya angka mikrofilaria rate $(>1 \%)$ dapat terjadi karena adanya penularan filariasis dari hewan ke manusia, manusia ke manusia dengan nyamuk sebagai vektornya. Selain angka Mf-rate yang tinggi, di wilayah Desa Bedono juga telah terjadi perubahan lingkungan seperti kerusakan hutan bakau (sejak tahun 2006) dan 
abrasi (sejak tahun 2009). Dampak negatif adanya perubahan lingkungan seperti kerusakan hutan bakau akan menyebabkan ledakan populasi dan distribusi nyamuk yang tidak terkendali hal ini terbukti dengan Angka Bebas jentik (ABJ) di Desa Bedono tahun 2016 belum mencapai target 95\% yaitu hanya 81,3\% (Dinkes Kabupaten Demak, 2016). Selain itu, Desa Bedono menggambarkan kekumuhan karena dampak dari abrasi menyebabkan $70 \quad \%$ pemukiman tergenang air rob disekitar rumah, $90 \%$ saluran pembuangan air limbah bersifat terbuka bercampur dengan genangan rob dan 80 $\%$ masyarakat tidak memiliki tempat penampungan sampah sehingga sampah banyak menumpuk dan berserakan di genangan air rob. Dengan hal ini, potensi nyamuk untuk berkembanngbiak dan menjadi vektor filariasis semakin tinggi serta penularan filariasis semakin meningkat.

Berdasarkan jenis mikrofilaria yang ditemukan di Desa Bedono yaitu spesies Wuchereria bancrofti, nyamuk yang berpotensi menjadi vektor utama adalah nyamuk Anopheles $s p$, Culex sp, dan Aedes sp (WHO, 2015). Selain itu, vektor utama filariasis Wuchereria bancrofti di daerah perkotaan adalah Culex quinquefasciatus, sedangkan di daerah pedesaan berbagai spesies Anopheles seperti An.subpictus, An.Barbirostris, An.Aconitus, An.Punctulatus, dan An.Farauti.

Pada hasil pendahuluan yang dilakukan di Desa Bedono pada bulan Maret tahun 2017 didapatkan bahwa nyamuk yang berpotensi menjadi vektor filariasis yaitu genus Culex $s p$., Anopheles sp., dan Aedes sp. Hal ini didukung dengan penemuan habitat potensial pada habitat alami dan buatan didapatkan $75 \%$ drum penampung air, $25 \%$ aquarium tidak terpakai, $25 \%$ ban bekas, dan $10 \%$ tempat minum ayam positif jentik nyamuk Aedes sp. sedangkan 67\% perahu terlantar, $67 \%$ selokan yang bercampur genangan rob, dan $30 \%$ sampah yang tergenang air payau di bantaran sungai dan genangan rob positif jentik nyamuk Culex sp. Berdasarkan hal tersebut, diketahui bahwa nyamuk yang diduga berpotensi menjadi penular filariasis di Desa Bedono yaitu nyamuk Aedes sp, Culex sp, dan Anophles sp dengan habitat potensial perkembangbiakan nyamuk berupa drum air, barang bekas, ban bekas, tempat minum ternak, dan selokan. Maka dari itu perlu dilakukan penelitian lebih lanjut terkait distribusi nyamuk dan habitatnya yang berpotensi menjadi vektor filariasis.

Potensi nyamuk menjadi vektor filariasis dapat dipengaruhi oleh kondisi lingkungan. Hal ini, karena nyamuk memiliki karakteristik perkembangbiakan sesuai lingkungan yang ditempati. Selain itu, perubahan lingkungan yang berubah dari waktu ke waktu akan berpengaruh terhadap kontribusi pertumbuhan vektor filariasis. Oleh sebab itu, perlu dilakukan perencanaan pengendalian vektor berbasis wilayah dengan menggunakan pendekatan spasial/pemataan. Distribusi spasial vektor filariasis merupakan tahap penting dalam perencanaan dan implementasi Program Pengendalian vektor yang tepat sasaran. Distribusi spasial dengan menggunakan Sistem Informasi Geografi (SIG) memungkinkan untuk membuat visualisasi berupa peta persebaran nyamuk dan tempat perindukan vektor filariasis sehingga memudahkan pengamatan sesuai kondisi penduduk dan wilayah. Tujuan dalam penelitian yaitu untuk menggambarkan sebaran vektor potensial filariasis dan habitatnya yang dilihat melalui pemetaan di Daerah endemis Desa Bedono, Kecamatan Sayung, Kabupaten Demak.

\section{METODE}

Penelitian ini dilakukan di Desa Bedono, Kecamatan Sayung, Kabupaten Demak dengan jumlah penduduk sebanyak $1.081 \mathrm{KK}$ yang terbagi atas 5 dusun yaitu Dusun Bedono, Dusun Morosari, Dusun Pandansari, Dusun Tonosari, dan Dusun Rejosari. Penelitian ini dilakukan selama bulan Mei - Juni 2017.

Penelitian ini menggunakan Jenis penelitian observasional dengan jenis rancangan penelitian deskriptif (explorative study) dengan pendekatan Sistem Informasi Geografi (SIG). Penggunaan studi observasional dalam penelitian ini dilakukan dengan survei entomologi pada vektor potensial filariasis dan 
habitat potensial perkembangbiakan di Desa Bedono.

Populasi penelitian ini yaitu seluruh nyamuk dewasa yang tertangkap serta habitat potensial perkembangbiakan nyamuk di wilayah penelitian di Desa bedono. Sampel spesies nyamuk adalah nyamuk Anopheles sp, Culex sp, dan Aedes sp. Sampel habitat potensial nyamuk adalah seluruh tempet-tempat potensial sebagai tempat perkembangbiakan nyamuk Anopheles sp, Culex $s p$, dan Aedes sp yang berada di lokasi penelitian. Pengambilan sampel nyamuk dewasa menggunakan tenik catching station. Penentuan catching station disesuaikan dengan karakteristik penggunaan lahan dan bioekologi nyamuk. Titik penangkapan yang dipilih yaitu area pemukiman, tambak, dan bakau. Sementara itu, teknik pengambilan sampel habitat potensial perkembangbiakan nyamuk dilakukan menggunakan teknik Accidental sampling pada masing-masing dusun di Desa Bedono.

Sumber data dalam penelitian ini yaitu data sekunder dan data primer. Data sekunder berupa laporan kasus filariasis (diperoleh dari laporan penyakit menular Dinas kesehatan Kabupaten Demak tahun 2016 dan Puskesmas Sayung I) dan jumlah data kepadatan penduduk (diperoleh dari Kantor Kelurahan). Data primer bersumber dari hasil observasi tentang survei entomologi nyamuk dewasa dan habitat perkembangbiakan nyamuk. Instrumen penelitian yang digunakan pada penelitian ini yaitu lembar observasi dan perangkat GPS. Lembar observasi digunakan untuk mencatat nyamuk yang tertangkap berdasarkan waktu dan lokasi penangkapan serta habitat potensial perkembangbiakan nyamuk yang ditemukan di wilayah penelitian serta perangkat GPS untuk melaksanakan digitasi. Alat dan bahan yang digunakan dalam pelaksanakan survei entomologi meliputi aspirator, senter, gelas plastik, kain kasa, karet gelang, gayung, pipet, botol, penggaris, alat tulis, label, keranjang, kapas, kertas label, larutan gula, dan formulir survei.

Prosedur penelitian dilakukan dengan beberapa langkah yaitu menentukan titik penangkapan nyamuk (titik lokasi pengamatan dalam penelitian ini yaitu pada area pemukiman, tanaman bakau dan tambak); menentukan habitat potensial perkembangbiakan nyamuk (survei jentik nyamuk dilakukan di perairan atau genangan air yang bersifat buatan); melakukan penangkapan nyamuk (penangkapan nyamuk dilakukan dengan menggunakan umpan orang di dalam rumah dan luar rumah pada malam hari pukul 18.00 - 06.00); melakukan survei habitat; pengambilan titik koordinat; proses pengiriman sampel nyamuk dewasa dan larva dari lapangan ke laboratorium; dan melakukan identifikasi serta pembedahan nyamuk.

Analisis data yang dilakukan pada hasil penelitian yaitu berupa analisis univariat dan data spasial. Analisis univariat berupa mengetahui distribusi nyamuk Anopheles sp, Culex $s p$, dan Aedes $s p$ yang berpotensi sebagai vektor filariasis; distribusi nyamuk Anopheles sp, Culex sp, dan Aedes sp berdasarkan waktu penangkapan; kepadatan spesies nyamuk, Kelimpahan nisbi, frekuensi spesies, dan dominasi spesies nyamuk yang berpotensi sebagai vektor filariasis, distribusi habitat potensial perkembangbiakan nyamuk Anopheles $s p$, Culex $s p$, dan Aedes $s p$ berdasarkan maya index (MI). Data yang ditampilkan dalam analisis univariat berupa tabel distribusi dan grafik. Data spasial dilakukan dengan mengumpulkan titik koordinat habitat potensial perkembangbiakan nyamuk di lokasi penelitian dengan menggunakan GPS dan selanjutnya dianalisis dengan menggunakan sistem informasi geografi (SIG). Data yang ditampilkan berupa pemetaan keruangan/wilayah.

\section{HASIL DAN PEMBAHASAN}

Berdasarkan hasil penelitian mengenai penentuan vektor potensial filariasis dengan penangkapan nyamuk dewasa yang dilakukan pada bulan Mei - Juni 2017 di Desa Bedono didapatkan total nyamuk tertangkap sebanyak 350 ekor dan dilakukan identifikasi untuk mengetahui spesiesnya serta dilakukan pembedahan untuk mengetahui adanya cacing 
Tabel 1. Distribusi Spesies Nyamuk berdasarkan lokasi penangkapan di Desa Bedono, Kecamatan Sayung, Kabupaten Demak pada Bulan Mei - Juni 2017

\begin{tabular}{|c|c|c|c|c|c|c|c|}
\hline \multirow{3}{*}{ Jenis Nyamuk } & \multicolumn{6}{|c|}{ Lokasi Penangkapan } & \multirow{3}{*}{$\begin{array}{c}\text { Hasil } \\
\text { Pembedahan } \\
\text { Nyamuk }\end{array}$} \\
\hline & \multicolumn{2}{|c|}{ Pemukiman } & \multicolumn{2}{|c|}{ Bakau } & \multicolumn{2}{|c|}{ Tambak } & \\
\hline & $\mathrm{Jml}$ & $\%$ & $\mathrm{Jml}$ & $\%$ & $\mathrm{Jml}$ & $\%$ & \\
\hline Cx. bitaenirhynchus & 16 & 5 & 5 & 20 & 2 & 20 & Negatif \\
\hline Cx. quinquefasciatus & 12 & 4 & 2 & 8 & 1 & 10 & Negatif \\
\hline Cx. Vishnui & 274 & 87 & 18 & 72 & 3 & 30 & Negatif \\
\hline Ae. Aegypti & 9 & 3 & 0 & 0 & 4 & 40 & Negatif \\
\hline An. Subpictus & 4 & 1 & 0 & 0 & 0 & 0 & Negatif \\
\hline Total & 315 & 100 & 25 & 100 & 10 & 100 & Negatif \\
\hline
\end{tabular}

mikrofilaria dalam tubuh nyamuk.

Berdasarkan hasil penelitian, diketahui bahwa spesies nyamuk Culex bitaenirhynchus, Culex quinquefasciatus, dan Culex. Vishnui merupakan nyamuk yang ditemukan pada semua lokasi penangkapan baik di area pemukiman, tambak, dan bakau. Hal tersebut disebabkan disekitar area lokasi penangkapan terdapat habitat potensial bagi ketiga spesies nyamuk tersebut yaitu banyak terdapat pembuangan air limbah rumah tangga dan selokan. Hal ini sesuai dengan penelitian Tallan (2016) menyatakan bahwa tempat ideal bagi tempat perkembangbiakan potensial nyamuk Culex quinquefasciatus di Kabupaten Sumba Barat berupa genangan air/kobakan yang ditemukan bersamaan nyamuk Culex bitaeniorhynchus, Culex vishnui, Anopheles Barbirorostris, dan Anopheles Vagus.

Distribusi nyamuk yang tertangkap di Desa Bedono berdasarkan tabel 1 menunjukkan bahwa nyamuk tertangkap paling banyak didapatkan pada lokasi pemukiman. Hal ini disebabkan karena sifat antropofilik nyamuk. Nyamuk betina memerlukan gula sebagai sumber energi dan nyamuk betina juga membutuhkan darah untuk proses pematangan telur. Hasil penelitian ini sejalan dengan penelitian Suwito (2010) bahwa keragaman nyamuk di wilayah pemukiman lebih tinggi dibandingkan dengan area tata guna lahan lainnya. Persentase Keanekaragaman nyamuk yang tertangkap di lokasi pemukiman yaitu berupa Culex bitaeniorhynchus (5\%), Culex vishnui (87\%), Culex quinquefasciatus (4\%), Aedes aegypti (3\%), dan Anopheles subpictus (1\%). Persentase
Keanekaragaman nyamuk yang tertangkap di lokasi bakau yaitu berupa Culex bitaeniorhynchus (20\%), Culex vishnui (72\%), dan Culex quinquefasciatus (8\%). Masela (2012) menyebutkan bahwa jenis nyamuk yang ditemukan di hutan mangrove/bakau yaitu Culex $s p$, Aedes sp, dan Anophles sp. yang dapat berkembangbiak di air kotor, air payau, dan air yang terperangkap di batang bekas tebangang bakau. Selain itu, Persentase Keanekaragaman nyamuk yang tertangkap di lokasi tambak yaitu berupa Culex bitaeniorhynchus (20\%), Culex vishnui (30\%), Culex quinquefasciatus (10\%), dan Aedes aegypti (40\%). Higa (2010) melaporkan bahwa nyamuk Culex sp. dan Aedes $s p$. ditemukan pada area tambak. Ditemukannya nyamuk Aedes aegypti pada area tambak dikarenakan disekitar area penangkapan terdapat habitat ban bekas yang diketahui melalui survei habitat dan didapatkan larva nyamuk spesies Aedes aegypti.

Kondisi lingkungan berperan dalam banyaknya jumlah nyamuk yang tertangkap saat penangkapan. Kepadatan nyamuk dewasa dipengaruhi oleh suhu dan kelembaban udara. Pengukuran suhu dan kelembaban udara dilakukan sepanjang malam disaat penangkapan nyamuk. suhu rata - rata saat penangkapan nyamuk di Desa Bedono berkisar $25-30^{\circ} \mathrm{C}$ sedangkan kelembaban udara rata - rata berkisar 66 - 96\%. Menurut Anggraini (2017), suhu dan kelembaban udara berpengaruh terhadap pertumbuhan, masa hidup serta keberadaan nyamuk. Suhu udara yang optimal bagi kehidupan nyamuk berkisar antara 25 $30^{\circ} \mathrm{C}$. Kelembaban udara berpengaruh terhadap 


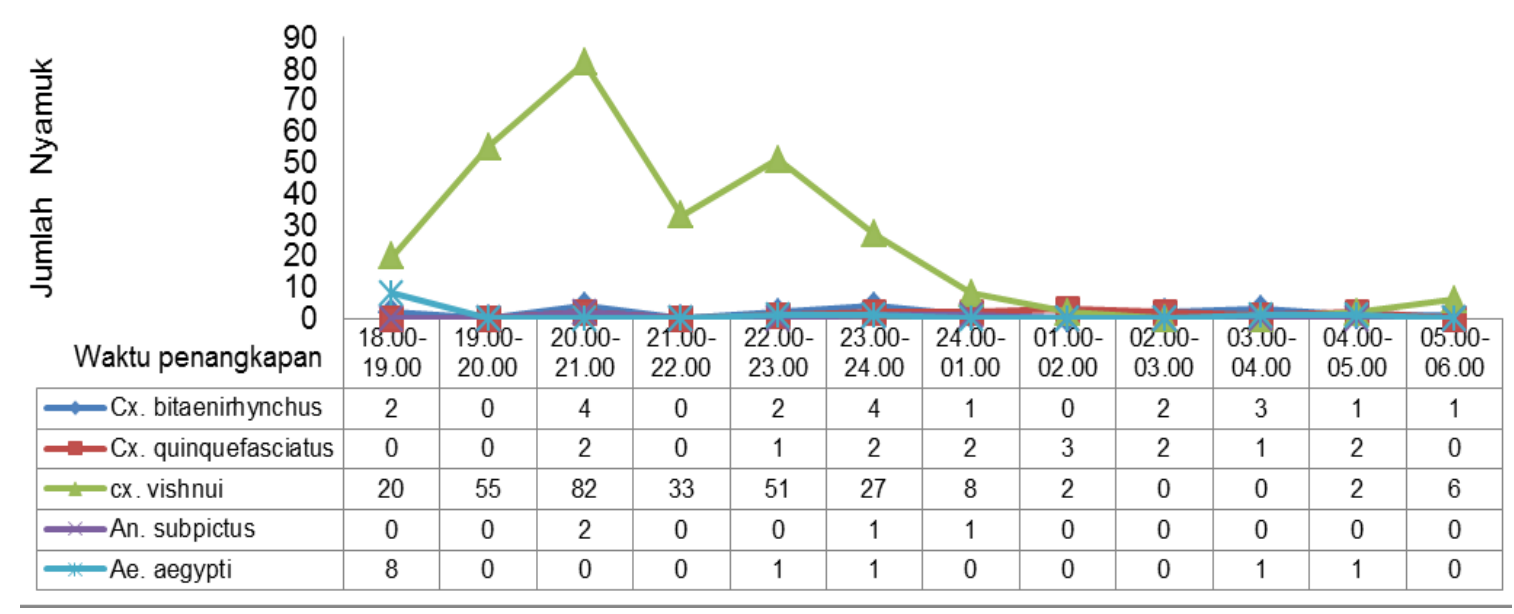

Gambar 1. Distribusi Spesies Nyamuk Berdasarkan Waktu Penangkapan di Desa Bedono

pertumbuhan, masa hidup, dan keberadaan nyamuk. Kelembaban yang rendah akan memperpendek umur nyamuk. Kelembaban mempengaruhi kecepatan berkembangbiak, kebiasaan menggigit, dan istirahat nyamuk. Tingkat kelembaban $60 \%$ merupakan batas paling rendah untuk memungkinkan hidupnya nyamuk sedangkan kelembaban yang tinggi menjadikan nyamuk aktif dan lebih sering menggigit sehingga meningkatkan penularan penyakit filariasis.

Hasil pembedahan dari 350 nyamuk tidak ditemukan mikrofilaria di dalam tubuh nyamuk. Hal ini diduga karena jumlah mikrofilaria di dalam darah hanya sedikit sehingga bisa dibunuh oleh pertahanan tubuh nyamuk. Kemampuan nyamuk untuk mendapatkan mikrofilaria saat menghisap darah yang mengandung mikrofilaria juga sangat terbatas, nyamuk yang menghisap mikrofilaria terlalu banyak dapat mengalami kematian, tetapi jika yang terhisap tcrlalu sedikit dapat memperkecil jumlah mikrofilaria stadium larva L3 yang akan ditularkan. Seseorang dapat terinfeksi filariasis apabila orang tersebut mendapat gigitan dari nyamuk vektor ribuan kali. Peluang untuk terinfeksi dari satu gigitan nyamuk vektor adalah sangat kecil. Meskipun tidak ditemukan cacing mikrofilaria saat pembedahan pada tubuh nyamuk, potensi nyamuk untuk menjadi vektor filariasis masih tinggi apabila masih ada sumber penularan. Penyebaran filariasis limfatik sangat ditentukan oleh kepadatan nyamuk yang berperan sebagai vektor penyakit.
Aktivitas menggigit spesies nyamuk yang tertangkap selama penangkapan di Desa Bedono dapat dilihat pada gambar 1 menunjukkan bahwa aktivitas menggigit tertinggi dimiliki oleh nyamuk Culex vishnui meningkat pada pukul $18.00-20.00$. Hal ini sejalan dengan penelitian Oktarina (2014) melaporkan bahwa kepadatan nyamuk Culex vishnui di Desa Tanjug Kemala Barat, Kabupaten Ogan Komering Ulu Timur bahwa waktu puncak aktivitas menggigit pada pukul 19.00-20.00. Penelitian lain melaporkan bahwa culex $s p$. di daerah endemis filariasis di Desa Empat, Kalimantan Selatan bahwa waktu puncak aktivitas Culex vishnui, Culex sitiens, Culex quinquefasciatus, dan culex fuslephalus pada pukul 19.00 - 20.00 dan 04.00 - 05.00 (Syahrial, 2005).

Aktivitas menggigit nyamuk Aedes aegypti meningkat pada pukul 18.00 - 19.00. Nyamuk Aedes aegypti biasanya mempunyai aktivitas menggigit pada siang hari, namun di Desa Bedono juga ditemukan aktif pada malam hari. Hal ini sejalan dengan penelitian Prasetyowati (2014) yang melaporkan Aedes aegypti mempunyai aktivitas menggigit yang meningkat pada malam hari (nokturnal) dari pukul 18.00 03.00 di pasar wisata pangandaran. Aktivitas menggigit Aedes aegypti malam hari juga dilaporkan oleh Hadi (2012) di berbagai daerah di Indonesia yaitu Cikawarang, Babakan, dan Cibanteng Kabupaten Bogor, Cangkurawuk Darmaga Bogor, Pulau Pramuka, Pulau Pari, Kepulauan Seribu, Gunung Bugis, Gunung 
Tabel 2. Kelimpahan nisbi, frekuensi spesies, dan dominansi spesies berdasarkan jenis nyamuk di Desa Bedono, Kecamatan Sayung, Kabupaten Demak pada bulan Mei - Juni 2017

\begin{tabular}{lcccc}
\hline \multicolumn{1}{c}{ Jumlah Nyamuk } & Jumlah & $\begin{array}{c}\text { Kelimpahan } \\
\text { Nisbi (\%) }\end{array}$ & $\begin{array}{c}\text { Frekuensi } \\
\text { Spesies }\end{array}$ & Dominansi Spesies \\
\hline Cx. bitaenirhynchus & 23 & 6,6 & 0,5 & 3,3 \\
Cx. quinquefasciatus & 15 & 4,3 & 0,5 & 2,2 \\
Cx. Vishnui & 295 & 84,3 & 1 & 84,3 \\
Ae. aegypti & 13 & 3,7 & 1 & 3,7 \\
An. subpictus & 4 & 1,1 & 0,5 & 0.6 \\
\hline
\end{tabular}

Karang, Gunung Utara Balikpapan, Kayangan, dan Lombo Utara

Kelimpahan nisbi, frekuensi, dan dominansi spesies tertinggi pada jenis nyamuk Culex vishnui, sedangkan dominansi spesies tertinggi pada jenis nyamuk Culex vishnui $(84,3)$ dan Aedes aegypti (3,7\%) dengan frekuensi masing-masing (1) seperti tersaji pada tabel 2. Ramadhani dan Wahyudi (2015) melaporkan bahwa angka dominansi dan kelimpahan nisbi yang paling tinggi di Kota Pekalongan yaitu Nyamuk Cx.quinquefasciatus $(79,42)$ yang diikuti oleh nyamuk $C x$ vishnui $(5,54)$.

Angka dominansi dapat menggambarkan kepadatan populasi nyamuk yang sebenarnya di suatu daerah dibandingkan parameter kepadatan yang lain. Selain itu, faktor dominansi spesies merupakan salah satu faktor yang diperhitungkan untuk memperkirakan potensi nyamuk menjadi vektor penularan penyakit. Dominansi spesies tertinggi pada penangkapan umpan orang yaitu dari jenis nyamuk Culex vishnui $(84,3)$, selanjutnya spesies nyamuk Aedes aegypti $(3,7)$ dengan frekuensi spesies masing-masing 1 seperti yang tersaji pada tabel 2. Hal tersebut dapat menunjukkan bahwa nyamuk Culex vishnui dan Aedes aegypti lebih memiliki kesesuaian sebagai vektor potensial potensial penularan filariasis di Desa Bedono. Culex vishnui memiliki nilai dominansi paling tinggi tetapi nyamuk jenis ini belum pernah dilaporkan menjadi vektor filariasis di Indonesia. Di Indonesia sendiri Culex vishnui dilaporkan menjadi vektor penyakit Japanese Encephalitis (JE), akan tetapi tidak menutup kemungkinan menjadi peluang vektor penularan filariasis karena kepadatan populasinya tinggi.
Aedes sp berdasarkan karakteristik anatominya memang dapat berperan sebagai vektor filariasis dan hal ini dibuktikan dengan penelitian-penelitian yang dilakukan di kawasan pasifik, namun yang menjadi perbedaan adalah kawasan pasifik tersebut periodisitas mikrofilarianya cenderung diurnal. Hal ini berbeda dengan Indonesia yang sampai saat ini masih ditemukannya periodisitas mikrofilaria bersifat nokturnal. Akan tetapi, pada penelitian ini ditemukan aktivitas nyamuk Aedes aegypti pada malam hari (nokturnal) sehingga tidak menutup kemungkinan terjadinya perubahan aktivitas menggigit nyamuk tersebut dan dapat perpeluang sebagai vektor penularan filariasis.

Selain faktor yang mendukung nyamuk menjadi vektor potensial filariasi juga terdapat faktor penghambat nyamuk sebagai vektor filariasis di antaranya adanya cibiral armatures. cibiral armatures yaitu duri-duri halus pada faring yang mampu membunuh 30-96\% mikrofilaria yang terhisap, misalnya pada Anopheles farauti dan Anopheles gambiae, namun ketika jumlah mikrofilaria yang terhisap tinggi dapat menyebabkan cibiral armatures tertutup oleh mikrofilaria sehingga mikrofilaria lainnya dapat lewat ke usus tengah (midgut) (Amuzu, 2010). Nyamuk yang tidak memiliki cibiral armatures dalam penelitian ini adalah Aedes aegypti, sehingga lebih berpeluang menjadi vektor filariasis di Desa Bedono.

Berdasarkan hasil pengamatan pada saat penelitian diketahui bahwa jenis habitat potensial yang dijumpai di Desa Bedono sebanyak 50 titik yang terdiri dari 7 jenis habitat (Tabel 4) dan tersebar di empat dusun, yaitu Dusun Pandansari, Morosari, Bedono, dan 
Tabel 3. Distribusi Habitat Potensial Perkembangbiakan Nyamuk

\begin{tabular}{|c|c|c|c|c|c|c|c|}
\hline \multirow{2}{*}{ Dusun } & \multicolumn{2}{|c|}{ Controlable Site } & \multicolumn{2}{|c|}{ Dispossible Site } & \multirow{2}{*}{$\begin{array}{l}\text { Hygiene Risk } \\
\text { Index (HRI) }\end{array}$} & \multirow{2}{*}{$\begin{array}{l}\text { Breeding Risk } \\
\text { Index (BRI) }\end{array}$} & \multirow{2}{*}{$\begin{array}{c}\text { Maya } \\
\text { Index (MI) }\end{array}$} \\
\hline & $(+)$ & $(-)$ & $(+)$ & $(-)$ & & & \\
\hline Pandansari & 2 & 1 & 0 & 0 & 0 & 4,3 & Rendah \\
\hline Morosari & 12 & 5 & 14 & 8 & 34,92 & 23,94 & Tinggi \\
\hline Rejosari & 0 & 0 & 0 & 0 & 0 & 0 & Rendah \\
\hline Bedono & 2 & 1 & 2 & 0 & 2 & 4,3 & Rendah \\
\hline Tonosari & 1 & 1 & 0 & 1 & 0 & 4 & Rendah \\
\hline
\end{tabular}

Tonosari. Habitat potensial perkembangbiakan nyamuk paling banyak ditemukan di Dusun Morosari dengan ditemukan 39 titik dengan 26 titik positif jentik dan 13 titik negatif jentik dengan habitat yang ditemukan berupa drum air, barang bekas, selokan, kolam ikan, ban bekas, tambak, dan tempat minum ternak. Selanjutnya 5 titik di Dusun Bedono dengan ditemukan 4 titik positif jentik dan 1 titik negatif jentik dengan habitat yang ditemukan berupa drum air, selokan, dan tempat minum ternak. Pada Dusun Tonosari ditemukan 3 titik dengan 2 titik postif jentik dan 1 titik negatif jentik dengan habitat yang ditemukan berupa drum air, tambak, dan tempat minum ternak. Di Dusun Pandansari ditemukan 3 titik dengan 1 positif jentik dan 2 titik negatif jentik pada habitat drum air dan tempat minum ternak.

Maya index (MI) merupakan Indikator yang dipakai untuk mengidentifikasi suatu area berisiko sebagai tempat perkembangbiakan nyamuk. Dusun dengan maya index (MI) tinggi di Desa Bedono yaitu Dusun Morosari terlihat dengan tingginya nilai Hygiene Risk Index (HRI) 34,92 (Tinggi) dan Breeding Risk Index (BRI) 23,94 (Tinggi). Hygiene Risk Index (HRI) dan Breeding Risk Index (BRI) tinggi menunjukkan banyaknya tempat yang tidak terkontrol (Dispossible Site) dan tempat terkontrol (Controlable Site) yang ditemukan di Dusun Morosari. Dispossible Site yang ditemukan berjumlah 22 titik dengan 14 titik positif larva diantaranya adalah selokan, barang bekas, ban bekas, dan kolam ikan tak terpakai, sedangkan

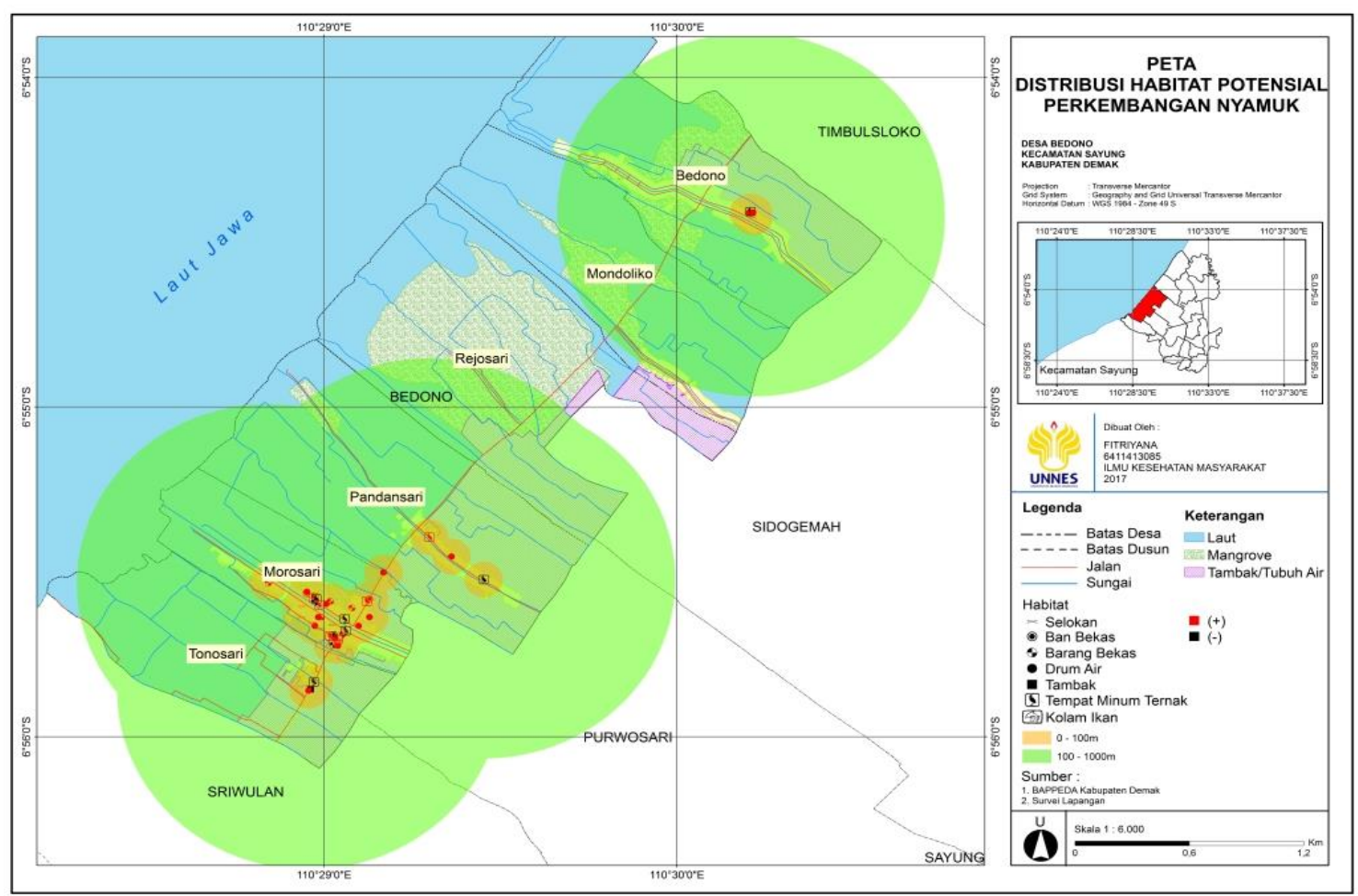

Gambar 2. Distribusi Habitat Potensial Perkembangbiakan Nyamuk 
Controlable Site yang ditemukan berjumlah 17 titik dengan 12 titik positif larva diantaranya adalah drum air di luar rumah, dan tempat minum ternak.

Nilai Maya Index (MI) rendah terdapat pada 3 dusun di Desa Bedono yaitu Dusun Tonosari, Pandansari, dan Bedono. 3 dusun tersebut juga memiliki nilai Hygiene Risk Index (HRI) dan Breeding Risk Index (BRI) rendah sehingga menunjukkan bahwa terdapat sedikit tempat yang tidak terkontrol (Dispossible Site) dan tempat terkontrol (Controlable Site).

Hasil survei jentik nyamuk pada habitat potensial perkembangbiakan nyamuk didapatkan 3 spesies nyamuk yaitu Aedes aegypti, Culex vishnui, dan Culex quinquefqsiatus. Hal ini berbeda dengan penangkapan nyamuk dewasa yang ditemukan 5 spesies nyamuk yaitu Aedes aegypti, Anopheles subpictus, Culex bitaeniorhnchus, Culex vishnui, dan Culex quinquefqsiatus. Berdasarkan penentuan vektor potensial filariasis berdasarkan dominansi spesies saat penangkapan nyamuk dewasa, spesies nyamuk yang perlu diwaspadai di Desa Bedono yaitu Culex vishnui dan Aedes aegypti. Hal ini didukung oleh banyaknya habitat perkembangbaiakan nyamuk tersebut yang tersebar di Desa Bedono. Gambar 2 menunjukkan bahwa distribusi spesies nyamuk terlihat mengumpul di Dusun Morosari dengan ditemukan spesies nyamuk Aedes aegypti, Culex vishnui, dan Culex quinquefqsiatus. Tingginya distribusi nyamuk yang ada di Dusun Morosari karena banyaknya habitat potensial perkembangbiakan nyamuk yang ditemukan. Hal ini karena Dusun Morosari merupakan wilayah dengan luas dan penduduk paling banyak di Desa Bedono. Hal ini sejalan dengan penelitian Yudhastuti (2005) yang menyatakan bahwa perkembangan pemukiman akibat didirikannya rumah-rumah baru yang dilengkapi dengan sarana pengadaan air untuk keperluan sehari-hari erat kaitannya dengan bertambahnya tempat-tempat perkembangbiakan nyamuk sehingga akan meningkatkan penyebaran populasi nyamuk.

Persebaran habitat potensial perkembangbiakan nyamuk yang ditemukan di Desa Bedono sebanyak 50 titik dengan 33 titik positif jentik dan 17 titik negatif jentik. Berdasarkan peta distribusi habitat potensial perkembangbiakan nyamuk terlihat bahwa Dusun Morosari merupakan dusun yang paling banyak ditemukan habitat potensial perkembangbiakan nyamuk. Habitat potensial yang positif paling banyak ditemukan pada habitat drum air, barang bekas, selokan, kolam ikan, ban bekas, dan tempat minum ternak.

Banyaknya jumlah perkembangbiakan nyamuk di Dusun Morosari disebabkan karena dusun ini merupakan dusun terluas serta dengan jumlah penduduk terbanyak di Desa Bedono. Hal ini terlihat dengan status Maya Index (MI) memiliki kategori tinggi berdasarkan nilai Breeding Risk Index (BRI) atau Hygiene Risk Index (HRI) yang tinggi. Selain banyaknya habitat potensial perkembangbiakan nyamuk yang ditemukan, Dusun Morosari merupakan dusun dengan ditemukannya kasus filariasis kronis dan kasus baru.

Penularan penyakit filariasis tidak lepas dari peran nyamuk sebagai vektor filariasis dan adanya sumber penularan (WHO, 2016). Salim (2015) menjelaskan bahwa orang yang hidup dekat dengan keberadaan breeding palces meningkatkan resiko penularan filariasis. Pernyataan ini juga didukung oleh penelitian Yunarko (2016) yang menyatakan bahwa Persebaran filariasis di Desa Kahale, NTT terdistribusi berdekatan dengan tempat potensial perkembangbiakkan nyamuk.

Habitat yang ditemukan di Desa Bedono merupakan habitat yang sangat potensial sebagai tempat perkembangbiakan jentik nyamuk dengan ditemukankannya spesies nyamuk yang menjadi vektor potensial filariasis. Berdasarkan penentuan vektor potensial filariasis di Desa Bedono didapatkan bahwa spesies nyamuk yang perlu diwaspadai yaitu Culex vishnui dan Aedes aegypti terlihat pada peta distribusi persebaran jentik nyamuk tersebut mendominasi di beberapa dusun. Habitat potensial yang ditemukan di Dusun Morosari merupakan area yang potensial atau berisiko sebagai tempat perkembangbiakan nyamuk.

Penyebaran vektor filariasis dalam menularkan penyakit filariasis erat kaitannya 
dengan jarak terbang nyamuk dari habitat perkembangbiakan. Terlihat pada peta zona buffer persebaran nyamuk dapat diprediksikan sejauh mana nyamuk bisa terbang dari habitat perkembangbiakan. Analisis zona buffer ditentuan berdasarkan jarak terbang rata-rata nyamuk. Berdasarkan analisis nyamuk yang berpotensi menjadi vektor cacing $W$. bancrofti yaitu genus Culex sp., Anopheles sp., dan Aedes sp. jarak terbang rata-rata nyamuk betina dari masing-masing genus yaitu Culex betina berkisar 200 - 2000 m, Anopheles berkisar $300-500$ m, sedangan Aedes betina berisar $100 \mathrm{~m}$ (WHO, 2016). Menurut Heriyanto (2011), rata-rata jarak terbang beberapa nyamuk sebagai vektor filariasis yang diasumsikan berjarak kurang lebih 900 meter sedangkan menurut penelitian Erlan (2014) menyatakan bahwa nyamuk pada umumnya mempunyai daya terbang sejauh 50 100 meter. Jarak terbang nyamuk dipengaruhi juga oleh arah dan kecepatan angin.

Buffering ada zona $<100$ meter menunjukkan nyamuk yang berasal dari titik habitat potensial memiliki jangkauan terbang masih berada pada masing-masing dusun. Titik habitat potensial paling banyak yang ditemukan pada jarak $<100$ dari titik kasus berjumlah 38 titik yang berada pada Dusun Morosari. Sehingga dapat dikatakan bahwa rumah dengan jarak $<100$ meter dari titik kasus memiliki resiko lebih besar tertular filariasis. Hal ini karena jarak terbang nyamuk yang kurang dari 200 meter akan sangat berpeluang terjadinya penularan filariasis (Asong, 2016).

Buffering pada zona $<1000$ meter menunjukkan bahwa habitat potensial perkembangbiakan nyamuk yang berada di Dusun Morosari mampu terbang melewati dusun dan desa lain yaitu mampu mencapai Dusun Pandansari dan Tonosari serta Desa Purwasari dan Sriwulan. Hal ini karena Dusun Morosari sangat berpotensi atau berisiko sebagai tempat perkambangbiakan nyamuk yang menjadi vektor filariasis, apalagi di dusun ini terdapat sumber penularan sehingga mampu meningkatkan transmisi penularan penyakit filariasis, karena kasus filariasis berada pada jarak terbang rata-rata vektor filariasis.
Hasil penelitian ini menjelaskan bahwa habitat potensial perkembangbiakan nyamuk paling banyak ditemukan di dekat penderita filariasis. Kasus filariasis di Desa Bedono berada pada Dusun Morosari, sedangkan Dusun Morosari merupakan area berisiko sebagai tempat perkembangbiakan nyamuk yang menjadi vektor potensial filariasis. Hal ini dapat dikatakan bahwa penduduk yang tinggal di Dusun Morosari beresiko paling besar tertular penyakit filariasis. selain itu, penduduk yang tinggal $<1000$ meter juga berpotensi tertular filariasis sehingga diperlukan prioritas untuk pencegahan dan pengendalian terhadap penularan filariasis (Heriyanto, 2011).

\section{PENUTUP}

Berdasarkan uraian di atas, dapat disimpulkan bahwa spesies nyamuk yang perlu diwaspadai sebagai vektor potensial filariasis di Desa Bedono yaitu nyamuk Culex vishnui dan Aedes aegypti. Habitat potensial perkembangbiakan kedua nyamuk tersebut tersebar di seluruh wilayah di Desa Bedono. Habitat Potensial perkembangbiakan nyamuk yang ditemukan di Desa Bedono yaitu berupa drum air, selokan, tempat minum ternak, barang bekas, kolam ikan, ban bekas, dan tambak dengan distribusi paling banyak ditemukan di Dusun Morosari. Dusun Morosari merupakan dusun dengan area berisiko sebagai tempat perkembangbiakan nyamuk, selain itu juga ditemukannya kasus filariasis kronis dan kasus baru di dusun ini. Hal ini dapat dikatakan bahwa penduduk yang tinggal di Dusun Morosari beresiko paling besar tertular penyakit filariasis. Risiko penularan filariasis juga dapat menyebar hingga ke dusun dan desa lain yaitu Dusun Tonosari dan Pandansari, serta Desa Sriwulan dan Purwosari.

Penelitian ini hanya berfokus pada habitat perkembangbiakan nyamuk yang bersifat buatan dan tidak dilakukan pengukuran terkait karakteristik habitat pada lokasi penelitian. Oleh karena itu, saran bagi penelitian berikutnya yaitu dilakukannya survei habitat perkembangbiakan nyamuk yang bersifat alami 
serta dilakukan pengukuran karakteristik habitat sehingga didapatkan jenis spesies nyamuk lainnya yang berpotensi menjadi vektor filariasis di Desa Bedono.

\section{DAFTAR PUSTAKA}

Amuzu H., Wilson M.D., Boakye D.A. 2010. Studies of Anopheles gambiae s.l (Diptera: Culicidae) Exhibiting Different Vectorial Capacities in Lymphatic Filariasis Transmission in The Gomoa District, Ghana. Parasites. Parasites \& Vectors, 3(85): 2-6

Anggraini, T.S., dan Cahyati, W.H. 2017. Perkembangan Aedes Aegypti Pada Berbagai $\mathrm{Ph}$ Air dan Salinitas Air. HIGEIA, 1 (3): 1-10

Asong, Arfan, I., Suharno. 2016. Analisis Spasial Risiko Lingkungan Dengan Kejadian Filariasis Di Wilayah Kerja Puskesmas Sungai Asam Kecamatan Sui Raya Kabupaten Kubu Raya 2016. Skripsi. Pontianak: Universitas Muhammadiyah Pontianak

Erlan, Ahmad. 2014. Promosi Kesehatan Dalam Pengendalian Filariasis. Balaba. Vol 10 (2): 90

Dinkes Kabupaten Demak. 2016. Laporan Tahunan Dinas Kesehatan Demak Tahun 2016. Demak: Dinas Kesehatan Kabupaten Demak

Hadi, U.K., Soviana, S., Gunandini, D.D. 2012. Aktivitas Nokturnal Vektor Demam Berdarah Dengue di Beberapa Daerah di Indonesia. JEI, 9 (1): 1-6

Higa, Y., Yen, N. T., Kawada, H., Son, T. H., Hoa, N. T., Takagi, M. 2010. Geographic Distribution of Aedes aegypti and Aedes albopictus Collected from Used Tires in Vietnam. Journal of the American Mosquito Control Association, 26(1):1-9

Heriyanto, B., Boewono, D.T., Widiarti, Boesri, H., Widyastutu, U., Blondine, C.P., Sowasono, H., Ristiyanto, Pujiyanti, A., Alfiah, S., Prastowo, D., Anggraini, Y.M., Irawan, A.S., Mujiyono. 2011. Atlas Vektor Penyakit di Indonesia. Jakarta: Kementerian Kesehatan RI

Kementerian Kesehatan RI. 2015. Infodatin: Filariasis Menuju Elimininasi Filariasis 2020. Jakarta: Kementerian Kesehatan RI

Masela, D. F. 2012. Pengaruh Struktur Dan Komposisi Mangrove Bagi Kerapatan Nyamuk Di Desa Kopi Dan Desa Minanga Kecamatan Bintauna. Jurnal Cocos, 1 (2): 1-8
Naito, Haruo. 2015. Esai to Provide Diethylcarbamazine Citrate Tablets Free of Charge for use in National Lymphatic Filariasis elimination Campaign in Indonesia. Human Health care: $15-70$

Prasetyowati, H., Marina, R., Hodijah, DN., Widawati, M., Wahono, T. 2014. Survey Jentik dan Aktifitas Nokturnal Aedes Spp. di Pasar Wisata Pangandaran. Jurnal Ekologi Kesehatan, 13 (1): 33-42

Oktarina, R., Yahya, Salim, M., Pahlevi, I. 2014. Keragaman Spesies Nyamuk Di Desa Pemetung Basuki Dan Desa Tanjung Kemala Barat Kabupaten Ogan Komering Ulu Timur. SPIRAKEL, 6: 14-25

Ramadhani, T. dan Wahyudi, B.F. 2015. Keanekaragaman dan Dominasi Nyamuk dinggara Timur. BALABA,12 (2): 89-98

Syahrial, Z., Santi, M., Ririh, Y., Hasan, A. 2005. Populasi Nyamuk Dewasa di Daerah Endemis Filariasis Studi di Desa Empat Kecamatan Simpang Empat Kabupaten Banjar Tahun 2004. Jurnal Kesehatan Lingkungan, 2 (1): 85-96

Salim, M.F., Satoto, T.B.T., Kusnanto, H. 2016. Zona Kerentanan Filariasis Berdasarkan Faktor Risiko dengan Pendekatan Sistem Informasi Geografis. Journal of Information Systems for Public Health, 1 (1):16-24

Suwito, Hadi, U.K., Sigit, S.H., Sukawati, S. 2010. Distribusi Spasial dan Bioekologi Anopheles Spp. di Lampung Selatan Dan Pesawaran, Provinsi Lampung. Jurnal Ekologi Kesehatan, 9 (3): 1290-1302

Tallan, M.M., dan Mau, F. 2016. Karakteristik Habitat Perkembangbiakan Vektor Filariasis di Kecamatan Kodi Balaghar Kabupaten Sumba Barat Daya. Aspirator, 2 (8): 55-62

WHO. 2016. Lymfatic Filariasis (Epidemiologi): The Vektor. Geneva: WHO Press

Yudhastuti, R. dan Vidiyani, A. 2005. Hubungankondisi Lingkungan, Kontainer, dan Perilaku Masyarakat dengan Keberadaan Jentik Nyamuk Aedes Aegypti di Daerah Endemis Demam Berdarah Dengue Surabaya. Jurnal Kesehatan Lingkungan, 1 (2): 170-182

Yunarko, R. dan Yona, P. 2016. Distribusi Filariasis Brugia Timori dan Wuchereria Bancrofti di Desa Kahale, Kecamatan Kodi Balaghar, Kabupaten Sumba Barat Daya, Nusa Tenggara Timur. BALABA, 12 (2): 89-98 